\title{
PROTECTING THE RIGHTS OF THE CHILD FROM VIOLENCE: ARE THE POWERS OF THE NATIONAL POLICE OF UKRAINE SUFFICIENT?
}

Kuznichenko S. O., Starychenko A. 0.

The purpose of this study is to identify legislative problems experienced by officers of the National Police of Ukraine in protection of the rights of children from manifestations of violence and abuse. The article deals with the phenomenon of manifestations of violence against children. Brief history of the origin and social formation of the studied phenomenon has been given along with the philosophical reflection in the mass consciousness of society. Some elements of the conceptual and categorical apparatus of juvenile legal relations have been defined. Formation of modern scientific theories about the phenomenon of violence against children in philosophy, psychology, pedagogy and law has been described. Statistics of crimes committed against children and manifestations of domestic violence in Ukraine has been given. It has been found that a significant part of Ukrainian society considers admissible the use of pedagogical coercion in the form of physical punishment of the child, and determines corporal punishment as a lawful and correct way of upbringing.

The system of national and international legislation regulating the prevention of violence against children has been studied. The main reasons that contribute to the emergence of violence against children have been outlined, including: social, economic, psychological, pedagogical, socio-pedagogical, legal, political, socio-medical, physiological and medical. Violence against children is an interdisciplinary problem that links law, health, psychology, pedagogy and sociology; it is characterized by a high level of latency. The legal acts providing the powers to the National Police in this field have been studied. The main legal and organizational problems that negatively affect the law enforcement during the exercise of powers by the National Police in the field of prevention of violence and abuse of children have been highlighted.

It has been concluded that the powers of the National Police of Ukraine in the field of legal protection of children from violence provided by current legislation are limited and do not allow them to effectively use the prevention tools.

Key words: children's rights, protection of children's rights, violence, National Police, juvenile prevention.

Кузніченко С. О., Стариченко А. О. Захист прав дитини від проявів насильства: чи достатньо повноважень Національної поліції України?

Метою цього дослідження $\epsilon$ виявлення законодавчих проблем, з якими зіштовхуються уповноважені посадові особи Національної поліції України при правозастосуванні під час діяльності із захисту прав дітей від насильницьких проявів та жорстокого поводження. У статmі розглянуто феномен насильницьких проявів стосовно дітей. здійснено короткий історичний екскурс виникнення та соціального становлення досліджуваного явища та його філософська рефлексія в масовій свідомості суспільства. Розкрито окремі елементи понятійно-категоріального апарату ювенальних правовідносин. Описано шлях становлення сучасних наукових теорій про феномен насильства над дітьми у філософії, психології, педагогіці та праві. Приведено статистичні дані вчинених злочинів стосовно дітей та проявів домашнього насильства в Україні. 3'ясовано, що значна частина українського суспільства вважає допустимим застосування педагогічного примусу саме через фізичне покарання дитини, а тілесне покарання визначає правомірним і правильним способом виховання.

Досліджено систему національних та міжнародних нормативно-правових актів, направлених на регулювання запобігання насильству стосовно дітей. Окреслено основні причини, що сприяють виникненню насильницьких проявів стосовно дітей, серед яких: соціальні, економічні, психологічні, педагогічні, сочіально-педагогічні, правові, політичні, соціально-медичні, фізіологічні та медичні. 3'ясовано, що застосування насильства стосовно дітей становить міждисциплінарну проблему, яка пов'язує право, охорону здоров'я, психологію, педагогіку та соціологію i характеризується високим рівнем латентності. Досліджено нормативно-правові акти, направлені на встановлення повноважень Національної поліції у сфері запобігання насильству стосовно дітей. Виділено основні правові та організаційні проблеми, що негативно впливають на досягнення правоохоронного ефекту під час реалізації посадовими особами Національної поліції повноваження під час здійснення діяльності у сфері запобігання насильства та жорстокого поводження з дітьми.

Зроблено висновок, що повноваження Національної поліції України, встановлені чинним законодавством України у сфері правового захисту дітей від

(c) Kuznichenko S. O., Starychenko A. O., 2020 
насильницьких проявів, є обмеженими та не дозволяють їм ефективно застосовувати інструменти превенції.

Ключові слова: права дітей, захист прав дітей, насильство, Національна поліція, ювенальна превенція.

The idea of children's rights is inextricably linked to the phenomenon of human rights and freedoms, which started to be enshrined in laws with the development of writing. National and international institutions obliged to the society to provide child protection emerged. Despite the development of modern system of legal protection violence accompanies the lives of a significant number of Ukrainian children. The most common and most difficult for prevention is domestic violence. The reason for this is not only the moral justification and acceptance of violence as a method of raising children, but also the imperfection of Ukrainian legislation.

Fundamental studies on which modern theories of violence are based have been conducted by Herbert Blumer, Max Weber, Johann Galtung, Ludwig Gumplowicz, Ralph Dahrendorf, Emil Durkheim, Georg Simmel, Lewis Coser, Robert K. Merton, Gaetano Mosca, William Graham Sumner, Neil Smelser, Albion Woodbury Small, Pitirim Sorokin, Oswald Spengler, Gabriel Tarde, Sigmund Freud, Erich Fromm and others.

Issues of legal protection and defense of children's rights have been thoroughly developed by national researchers such as V.I. Abramov, A.S. Avtonomov, H.O. Arkhipova, T.V. Bachynsky, I.V. Voloshina, O.I. Volokitenko, I.V. Voloshchuk, A.M. Hryshchuk, O.M. Druchek, O.E. Zhuravel, B.O. Zakrynytska, V.S. Zelenetsky, T.L. Kalchenko, T.G. KorzhIkaeva, S.P. Kotaleichuk, H.M. Krestovska, O.M. Kudriavtseva, O.O. Lazorenko, H.V. Lesko, O.V. Maksymenko, I.L. Mykhailova, V.Yu. Moskaliuk, O.V. Nikitenko, N.M. Onishchenko, R.M. Opatsky, N.M. Opolska, S.H. Povolotska, Zh.M. Pustovit, S.A. Sabluk, E.P. Filipenko, O.V. Cherevach, I.V. Shvets, O.A. Schultz and others.

However, the problems of police powers in prevention of violence against children and the ways of improving legislation in this field do not lose their relevance and therefore require new researches.

The purpose of this study is to identify the legislative problems faced by the National Police of Ukraine during protection of the rights of children from violence and abuse.

The Brockhaus and Efron encyclopedic dictionary, published in the late nineteenth century, interprets the term "violence" as the illegal use of force against the victim, forcing him to do or not do something, to experience something. Violence can be physical or mental; the latter is most often expressed in the form of threats. Violence can be an instrument of committing another crime (robbery, burglary, rape, encroachment on personal liberty); in this case it is a part of the mentioned crime. As an independent crime, violence consists in the illegal use of force against an individual who does not commit another crime"[1].

The phenomenon of violence has been under research since ancient times, it drew attention of philosophers, theologians and lawyers, continues to be the object of scientific attention today. Moreover, this phenomenon has influenced the formation of a number of scientific concepts, such as "philosophy of violence" (V. Kebuladze) [2], "ethnopedagogy of violence" (0. Kurochkin) [3], and finally "theory of violence" - one of the theories of state formation (in jurisprudence).

Violence is so deeply rooted in everyday life that it is reflected in the many proverbs of the world: "No cross, no crown" - England, "Mind is taught by a stick" Afghanistan, "Hit a tree on a knot and the stubborn on the back of the head" - Mongolia, "The stick is dumb, but gives some wisdom" - Russia, "He who does not obey the mind, obeys the cue" - France, "There is no education without a stick", "A student is more afraid of a cane than of a thunderstorms" Ukraine [4] and others.

The problem of violence against children is has historical roots. According to customary law and family traditions, corporal punishment of children was considered a common, normal way of upbringing. Humanity has not immediately come to understanding that a child is not the property of their parents or those who replace them and also a full member of a society. Only at the end of the Renaissance a child was recognized as a great social value. However until today this problem has not disappeared. According to the research by international humanitarian institutions, every year more than thirty million children are exposed to physical, sexual and psychological violence [5, p. 366].

Of course, the attitude towards children has changed significantly for the better. A child is considered a full member of society from birth and his or her life is protected by a number of international legal acts, including the Universal Declaration of Human Rights of 1948 [6], the 1959 Declaration of the Rights of the Child, adopted by the UN General Assembly [7] and the 1989 UN Convention on the Rights of the Child [8], the Convention against 
Torture and Other Cruel, Inhuman or Degrading Treatment or Punishment [9] and others.

Violence against children is prohibited under the national laws of the vast majority of countries in the world. According to the Constitution of Ukraine, everyone has the right to respect for his dignity. No one shall be subjected to torture or to cruel, inhuman or degrading treatment or punishment (Article 28). Childhood is protected by the state (Article 51). Children are equal in their rights regardless of their origin, whether they are born in or out of wedlock. Any violence against and exploitation of a child is prosecuted by law (Article 52) [10]. Among the national program documents aimed at protection of the rights and interests of children it is worth mentioning the Concept of the State Family Policy, approved by the Resolution of the Verkhovna Rada of Ukraine of September 17, 1999 № 1063-XIV [11]. A special place is taken by such laws as "On Child Protection" [12], "On Prevention and Counteraction to Domestic Violence" [13] and the Family Code of Ukraine, Article 150 of which oblige parents to care for the child's health, physical, spiritual and moral development; respect the child, it prohibits all forms of exploitation by the parents of their child, and corporal punishment, as well as any other types of punishment that degrade the human dignity of a child [14].

In addition, corporal punishment and illtreatment of children and other violent crimes are prohibited by a number of provisions of the Criminal Code of Ukraine: a) violence in crimes against the life and health of children; b) violence in crimes against the will, honor and dignity of children; c) violence in crimes against sexual freedom and sexual integrity of children; d) violence in crimes against the children [15, p. 73; 16].

However, violence against children is common in Ukraine despite the existence of a well-developed system of legal protection which provides a large number of legal prohibitions on the use of violence. In 2020 according to the Ministry of Internal Affairs of Ukraine 4.3 thousand crimes against children were recorded, from which 4.7 thousand children suffered. Almost 1,500 juveniles were victims of serious and especially serious crimes. Police processed more than 115,000 allegations and reports of domestic violence.

It should be noted that Ukraine is not the only country where violence against children is high. In most European countries, the level of violence against children has not been decreasing for several years in a row [18]. The adoption of international legislation as well as the international legal mechanisms of control serve as an effective platform for cooperation between states in this area and have to improve the situation in the field of preventing violence against children [19].

In administrative and judicial practice, there are many examples of the use of parenting techniques which according to the law can be classified as violence. To the false belief of such parents corporal punishment of a child is an effective form of pedagogical influence. It is problematic that a significant part of Ukrainian society associates pedagogical coercion with the physical punishment of a child, corporal punishment is treated as a correct way of upbringing. These relationships are thought to be personal matter of the family and state intervention in the sphere of domestic relations is unacceptable.

Such cases are not isolated. Police juvenile prevention units in each region document hundreds of cases in which violence in various phorms is a part of a "normal" family life and the latent part is significantly higher.

The Law of UkraineOnPreventionandCounteraction to Domestic Violence distinguishes four main forms of violence against children: economic violence; psychological violence; sexual violence; physical violence. The same law defines as an administrative offense any of these types of violence if there are no signs of a criminal offense [13].

Researchers of the phenomenon of violence describe it it as an interdisciplinary problem that connects law, health care, psychology, pedagogy, sociology [20, p. 7]. At the same time, within the interdisciplinary nature of violence against children, its main causes are distinguished:

- social (tensions, conflicts, violence in society, propaganda of violence as a model of behavior in the mass media);

- economic (poverty; lack of decent living conditions; unemployment; economic dependence);

- psychological (stereotypes of behavior);

- pedagogical (lack of culture of behavior legal, moral, civil, aesthetic, economic, labor);

- socio-pedagogical (lack of: parenthood, family values in a society, a positive model of family life on the basis of gender equality, family education based on the rights of a child);

- legal (attitude to violence as an internal family problem, not as a negative social phenomenon, to family members are treated as property; lack of legal awareness);

- political (tendency to gender stereotypes; gender inequality; attention to motherhood 
and childhood, not to the family in general; lack of attention to parenthood, men);

- socio-medical (lack of reproductive culture in the population, ir responsible parenthood, the poor system of family doctors; alcoholism, drug addiction, aggression, etc.);

- physiological and medical (disorders of hormonal background, metabolism, speed of reactions; taking stimulant drugs; diseases of the nervous system, etc.) [21, p. 26].

The powers of the police units of juvenile prevention in the field of prevention and counteraction to domestic violence are detailed in the Laws of Ukraine On National Police and On Prevention and Counteraction to Domestic Violence, the Order of the Ministry of Internal Affairs of Ukraine dated 19.12.2017 № 1044 On the instruction the organization of work of juvenile prevention units of National police of Ukraine [22]. Certain issues of prevention and counteraction to domestic violence in the part of police interaction with other authorities are regulated by the Resolution of the Cabinet of Ministers of Ukraine dated 22.08.2018 № 658 On approval of the Procedure for interaction of authorities in the field of prevention and counteraction to domestic and gender-based violence [23].

At the same time, the National Police officers face significant problems in the application of juvenile law.

1. Officers of the National Police of Ukraine are not authorized to initiate the issue of taking a child away from the parents. According to Part 2 of Article 170 of the Family Code of Ukraine, the decision to take the child away from the parents can be made only by the court. Even in exceptional cases, when there is an imminent threat to the life or health of the child, such a decision may be made by the guardianship authority or the prosecutor [14].

2. Counteraction to violence of the officials of the National Police is complicated by the high latency of crimes against children. The existing official statistics are far from reality and this is confirmed by numerous social surveys according to which $65-70 \%$ of children have experienced at least one type of violence [24] and that only $10 \%$ of children report violence to the police or in any other way [25].

3. Lack of powers of the National Police to initiate the process of deprivation of parental rights, as these issues are resolved by the court (Article 164 of the Family Code of Ukraine) [14].

4. A negative factor is absence in the Ukrainian legislation of the responsibility for failure to report a crime committed against a child in a family. Although such a crime is classified by criminal legislation of many countries [26].

Protective enforcement is made even more difficult by the provisions of Part 2 of Article 39 of the Criminal Code of Ukraine, which excludes criminal liability for unpromised concealment of a crime by a family member or a close relative of the person who committed the crime, the list is determined by law [16].

Summary. The study provides grounds to assert that the powers of the National Police of Ukraine set by the current Ukrainian legislation in the field of legal protection of children from violence are limited and do not allow police to use prevention tools effectively.

\section{References}

1. Entsiklopedicheskiy Slovar' F.A. Brokgauza i I.A. Yefrona (V 86 tomakh s illyustratsiyami i dopolnitel'nymi materialami). URL: http://www.vehi.net/ brokgauz

2. Vakhtanh Kebuladze. Filosofiya nasyl'stva. Zbruc. URL: https://zbruc.eu/node/90688

3. Kurochkin O. Etnopedahohika rizky. Ukrayintsi v sim'yi yevropeys'kiy: zvychayi, obryady, svyata. Kyyiv : Biblioteka ukrayintsya, 2004. 224 p.

4. Kurochkin O.V. Rytual "subitky" ta inshi metody etnopedahohiky pokarannya. Mahisterium. Vypusk 12. Kul'turolohiya. P. 61-67.

5. Gandzhi P. Issledovaniye semeynykh faktorov, vliyayushchikh na nasiliye nad det'mi so storony roditeley. Molodoy uchenyy. 2013. № 7. P. 366-368.

6. Universal Declaration of Human Rights of 1948: Declaration, International Document dated 10.12.1948. URL: https://zakon.rada.gov.ua/laws/show/995_015\#Text

7. Declaration of the Rights of the Child 1959: Declaration, International Document dated 20.11.1959. URL: https://zakon.rada.gov.ua/laws/show/995_384\#Text

8. UN Convention on the Rights of the Child: International document dated 20.11.1989. URL: https:// zakon.rada.gov.ua/laws/show/995_021\#Text

9. Convention against Torture and Other Cruel, Inhuman or Degrading Treatment or Punishment: Convention, International Document dated 10.12.1984. URL: https:// zakon.rada.gov.ua/laws/show/995_085\#Text

10. Constitution of Ukraine: Law of Ukraine; Constitution. Edited from 01.01.2020. URL: https:// zakon.rada.gov.ua/laws/show/254k/96-Bp\#Text

11. On the Concept of State Family Policy: Resolution of the Verkhovna Rada of Ukraine of 
September 17, 1999. URL: https://zakon.rada.gov.ua/ laws/show/1063-14\#Text

12. On Child Protection: Law of Ukraine of April 26, 2001. URL: https://zakon.rada.gov.ua/laws/show/ 2402-14\#Text

13. On Prevention and Counteraction to Domestic Violence: Law of Ukraine of December 7, 2017. URL: https://zakon.rada.gov.ua/laws/show/2229-19\#Text

14. Family Code of Ukraine: Code; Law of Ukraine, Edition of 01.01.2021. URL: https://zakon.rada.gov.ua/ laws/show/2947-14\#Text

15. Kostenko YA.V. Zlochyny proty dytyny: zmist ta klasyfikatsiya. Naukovyy visnyk Mizhnarodnoho humanitarnoho universytetu. Seriya : Yurysprudentsiya. 2017. Vypusk 30 (2). C. 72-75.

16. Criminal Code of Ukraine: Code; Law of Ukraine, Edition of 30.12.2020. URL: https://zakon.rada.gov.ua/ laws/show/2341-14\#Text

17. Torik dity povidomyly pro 1418 vypadkiv domashnoho nasylstva, - Fatsevych. LB.ua. URL: https: / / b.ua/society/2019/02/01/418602_proshlom_ godu_deti_soobshchili_1418.html

18. Gewalt gegen Kinder ist Alltag. Polizeiliche Kriminalstatistik. 2015. Artikel, 02.06.2016. URL: https:// www.tagesschau.de/inland/kindstoetungen $103 . \mathrm{html}$

19. Banis P.A., Il'yashevich M.V. Mezhdunarodno-pravovyye aspekty sotrudnichestva gosudarstv po bor'be s nasiliyem v otnoshenii detey: opyt Germanii. Probely $v$ rossiyskom zakonodatel'stve. 2016. № 8. P. 380-385.

20. Pravovi ta kryminolohichni zasady zapobihannya nasyl'stvu v sim'yi : navch. posib. / za zah. red. O.M. Dzhuzhi, I.V. Opryshka, O.H. Kulyka. Kyyiv : Nats. akad. vnutr. sprav Ukrayiny, 2005. 124 p.

21. Nasylstvo $v$ sim'yi ta diyalnist orhaniv vnutrishnikh sprav shchodo yoho podolannya: navchal'no- metodychnyy posibnyk dlya kursantiv vyshchykh navchal'nykh zakladiv MVS Ukrayiny / Ukladachi : A.V. Zaporozhtsev ta in. Kyyiv, 2012. 246 p.

22. On approval of the Instruction on the organization of work of juvenile prevention units of the National Police of Ukraine: Order of the Ministry of Internal Affairs of Ukraine dated 19.12.2017 № 1044. URL: https://zakon.rada.gov.ua/laws/show/z0686-18\#Text

23. On approval of the Procedure for interaction of entities carrying out measures in the field of prevention and counteraction to domestic violence and gender-based violence: Resolution of the Cabinet of Ministers of Ukraine dated 22.08.2018 № 658. URL: https:// zakon.rada.gov.ua/laws/show/658-2018-n\#Text

24. Rezultaty opytuvannya hromads'koyi dumky z pytan' nasyl'stva stosovno ditey / Informatsiyno-resursnyy tsentr «Dytynstvo bez nasyl'stva». URL: https: / / rescentre.org.ua/images/Uploads/Files/ statistika_dl/doslidzhenya_nasilstvo.pdf

25. Domashnye nasyl'stvo: zhakhlyva statystyka ta alhorytm diyi. Mayak media. URL: https://mayak. media/read/card/53287/domashne-nasilstvo-zhahliva-statistika-ta-algoritm-dii

26. Snyman C. Criminal Law. Fifth Edition. Durban : LexisNexis, 2008. 625 p.

Kuznichenko S. O., Doctor of Law, Professor,

Corresponding Member of the National Academy of Pedagogical Sciences of Ukraine, Vice-Rector National Academy of Internal Affairs

Starychenko A. O., Graduate Student Odessa State University of Internal Affairs 